Marquette University

e-Publications@Marquette

$11-1-2011$

\title{
The Incidence of the Mortgage Interest Deduction: Evidence from the Market for Home Purchase Loans
}

Andrew Hanson

Marquette University, andrew.r.hanson@marquette.edu

Accepted version. Public Finance Review, Vol. 40, No. 3 (May, 2012): 339-359. DOI. (C) 2012 Elsevier. Used with permission. 
The Incidence of the Mortgage Interest Deduction: Evidence from the Market for Home Purchase Loans

Accepted for Publication at Public Finance Review as of 7/18/2011

Andrew Hanson

Department of Economics, Georgia State University

\begin{abstract}
:
This paper examines the incidence of the largest housing related subsidy in the Federal budget, the home mortgage interest deduction (MID). I use the difference in interest rates for loans made around the \$1 million MID limit to identify the incidence of the subsidy. Using data on individual mortgages originated in 2004 , I estimate that for every $\$ 1,000$ borrowed without the MID, the interest rate on the entire loan decreases by between 3.3 and 4.4 percent. Results suggest that lenders capture between 9 and 17 percent of the subsidy created by the home mortgage interest deduction through higher mortgage interest rates.
\end{abstract}

Keywords: housing subsidy, mortgage interest deduction, incidence

JEL: H22, G21

I would like to thank Stacy Dickert-Conlin, John Harding, Jeff Kubik, Jon Rork, Todd Sinai, John Spry, Geoffrey Turnbull, Pete Wilcoxen, John Yinger, and two anonymous referees for helpful comments and suggestions. Any errors are my own. 


\section{INTRODUCTION}

The largest housing-related subsidy in the federal income tax code is the mortgage interest deduction (MID). Office of Management and Budget (OMB) estimates suggest the MID will reduce income tax revenues by over $\$ 104$ billion in fiscal year 2011 and by over $\$ 637$ billion between 2011 and 2015 (Executive Office of the President, 2010). ${ }^{1}$ There is a large literature that examines how the MID affects the user cost of housing, the decision to own or rent, and the price of the housing stock. ${ }^{2}$ These studies treat changes in the tax code that alter the value of the MID as exogenous factors that affect the demand for housing by lowering the net interest rate paid on debt financed housing. A common assumption in these studies is that the gross interest rate (before the tax deduction) on a mortgage is independent of the subsidy created by the $\mathrm{MID} ;{ }^{3}$ this is equivalent to assuming that the economic incidence of the MID subsidy falls entirely on borrowers.

This paper tests the validity of this assumption by examining if the availability of the MID affects the interest rate charged by lenders on home purchase loans, and then uses the results to determine what portion of the subsidy is captured by lenders. Knowing the economic incidence of the MID is important for a precise understanding of how the subsidy currently affects the housing market and, given the recent interest in altering or limiting the subsidy, ${ }^{4}$ how changing it would affect the housing market in the future. Models of housing costs in the existing literature do not account for MID-induced changes in the gross interest rate, and therefore may not precisely measure the impact of the existing policy and could mistake the effect of proposed policy changes.

To identify how the MID affects mortgage interest rates, this paper uses a rule in the federal tax code that limits the MID. The MID is limited based on the nominal amount of a 
mortgage, any interest paid on a mortgage over $\$ 1$ million is not tax deductible. ${ }^{5}$ The primary method used to identify the effect of the MID on interest rates is to compare the interest rate on marginal borrowing below the limit where all interest is deductible, with the interest rate on marginal borrowing above the limit where interest is no longer deductible. I also use a regression kink approach that compares the interest rate on loans within a smaller bandwidth around the MID limit and test for a difference in interest rate changes at the limit.

Using data from the Federal Financial Institutions Examination Council (FFIEC) on mortgage originations in 2004, I find that the interest rate on marginal borrowing above the MID limit, where the subsidy is lost on the marginal dollar borrowed, is significantly lower than marginal borrowing below the limit. Losing the MID reduces the interest rate on marginal borrowing by between 3.3 and 4.4 percent on home purchase loans. This estimate implies that between 9 and 17 percent of the subsidy created by the MID is offset by lenders charging a higher interest rate than they would in the absence of the MID.

The remainder of the paper begins with a brief discussion of some theoretical considerations and an explanation of how this paper extends the existing literature. Section III presents the strategy for identifying how the MID affects mortgage interest rates. Section IV discusses the data used for estimation and is followed by the main results and robustness checks (Section V). The final section of the paper concludes.

\section{THEORETICAL CONSIDERATIONS and EXISTING LITERATURE}

The standard model used to study the tax treatment of owner occupied housing is the user cost model (Rosen (1979a, 1979b, 1985), Poterba (1984, 1992), Green and Vandell (1999), Glaeser and Shapiro (2002), Himmelberg, Mayer and Sinai (2005), and Anderson, Clemens and Hanson (2007)). The model is based on the premise that the economic profit realized through 
home ownership should, in equilibrium, be driven to zero so that the annual rental price (or user cost) of owner occupied housing $(A)$ is equal to the annual cost associated with owning the home (which is a function of the purchase price $\left(P_{H}\right)$ ). Typically, the model includes costs such as the annual property tax rate $\left(\tau_{\mathrm{p}}\right)$, the opportunity cost of investing in housing or the interest rate that would be earned on an alternative asset $\left(R_{1}\right)$, the interest rate paid on a mortgage $\left(R_{2}\right)$, maintenance costs $(m)$, and house price inflation net of depreciation $(\pi)$, so that the rental price of housing is represented by some form of the following expression:

$$
A=\left[(1-\tau) \tau_{\mathrm{p}}+(1-\tau)(1-\theta) R_{1}+(1-\tau) \theta R_{2}+m-\pi\right] P_{H}
$$

where $\tau$ is the marginal income tax rate and $\theta$ is the share of the house that is financed with debt (where $\theta \leq 1$ ). The property tax term and the mortgage interest rate term are multiplied by one minus the marginal tax rate to reflect the value of the available tax deductions. The opportunity cost term is also expressed in after-tax terms.

Importantly, in this model the mortgage interest rate, $R_{2}$, is assumed to be independent of the MID, a potential shortcoming of the model that was recognized by Rosen (1979a). ${ }^{6}$ This assumption is crucial when using the model to determine how the current MID affects rents and house prices or to predict the impact of proposed changes to the tax code that would alter the MID because it implies that all tax changes will be completely passed through to house prices. To see this, consider using the model to calculate the effect of the MID on the annual rental price of owner occupied housing (A) for a $\$ 250,000$ home in the case where the borrower is able to capture the full value of the deduction versus a case where the lender captures 25 percent of the subsidy. ${ }^{7}$ If borrowers realize the full value of the tax deduction, then the model shows the annual rental price of housing to be 6.5 percent of the purchase price. If, on the other hand, lenders are able to capture 25 percent of the subsidy in the form of higher interest rates on the 
mortgage, the model shows the annual rental price increases by almost 6 percent to 6.9 percent of the purchase price.

This paper examines the possibility that the interest rate on a mortgage is, in fact, a function of the available tax deduction, or that lenders in the mortgage market capture some of the subsidy created by the MID by charging a higher interest rate. I suggest that the interest rate, $R_{2}$, is endogenous in the standard user cost model, and that it is a function of the available tax deduction $(\tau)$ and other borrower characteristics $(c)$ :

$$
R_{2}=\mathrm{f}(\tau, \mathrm{c})
$$

So that the user cost equation becomes:

$$
A=\left[(1-\tau) \tau_{\mathrm{p}}+(1-\tau)(1-\theta) R_{1}+(1-\tau) \theta R_{2}(\tau, \mathrm{c})+m-\pi\right] P_{H}
$$

To my knowledge, there has been no prior study of how the MID affects interest rates in the mortgage market. There are existing studies of the incidence of other housing related subsidies, notably, Gibbons and Manning (2006), Devereux and Lanot (2003), and Susin (2002). Devereux and Lanot parameterize a model of the UK housing market and estimate that lenders capture between 70 and 80 percent of the subsidy provided through preferred tax treatment of mortgage interest. Susin examines how the U.S. Section 8 housing subsidy for low income families affects the price of rental housing for both subsidized and unsubsidized renters. Susin does not measure the incidence of the Section 8 program directly, however, he does show that the program is responsible for a significant increase in housing prices, which results in a net loss of $\$ 2.4$ billion to low income families (a $\$ 5.8$ billion subsidy to recipients, and $\$ 8.2$ billion increase in rent paid by non-recipients).

The work presented here is similar in spirit to Gibbons and Manning (2006), who estimate the incidence of the U.K Housing Benefit subsidy for renters. They find that reducing 
the subsidy by 10 to 15 percent results in a 6 to 11 percent decrease in rents paid to landlords, which implies that landlords receive roughly two-thirds of the subsidy. Gibbons and Manning describe a theoretical framework for the incidence of the subsidy in both a perfectly competitive market and a market with imperfect competition. The model of imperfect competition, based on a matching model where renters and owners bargain over the rental price of housing, allows for multiple rental prices to exist in equilibrium. Gibbons and Manning (2003) present a detailed version of this model, based on the theoretical framework in Wheaton (1990). A similar theoretical model is implicit in this paper, as I look for the existence of different interest rates (prices) in the mortgage market.

Although it is beyond the scope of this paper to investigate the full set of reasons why price differentials exist in the mortgage market, it is necessary to show they exist to motivate how the MID may affect them. The existence of price differentials for the same product demonstrates that the price differential created by the MID may not be easily arbitraged away. Examining advertised interest rates in the U.S. mortgage market reveals that lenders typically advertise a single interest rate for a specific mortgage product (for instance, a 30 year loan with a fixed rate); however, the advertised rate varies substantially across lending institutions. Lender interest rates available through the financial publishing website bankrate.com demonstrate the variation that exists. ${ }^{8}$ A simple search for a 30 year fixed rate loan in a large metropolitan area on bankrate.com yields interest rate offers from 41 different lenders, each one of them unique, ranging in APR from 4.74 to 5.57, with a standard deviation of 21 basis points. 


\section{IDENTIFICATION STRATEGY and EMPIRICAL SPECIFICATION}

The MID is available to all taxpayers who itemize deductions and paid interest on a mortgage during the previous year. The amount of interest that a taxpayer can deduct from taxable income is limited based on size of the mortgage (and tax status, if the borrower is a married filing separately taxpayer). For mortgages used for the purpose of purchasing a home, taxpayers cannot deduct the excess interest paid on a mortgage over $\$ 1$ million. Interest paid on mortgages used for other purposes but secured by home-owner equity can also be deducted for loans up to $\$ 100,000$. $^{9}$

The nominal limit on deductibility provides an exogenous source of variation in the value of the MID that can be used for identifying how the MID affects the interest rate charged by lenders. To identify the effect of the MID subsidy on interest rates, I use OLS estimation and Regression Kink Design (RKD) estimation following Card, Lee, and Pei (2009).

\subsection{Marginal Borrowing for Loans Above the Limit}

If lenders capture some of the subsidy created by the MID, then eliminating the subsidy on marginal borrowing will reduce the gross interest rate (charged by lenders) for loans made above the limit. To test how removing the MID affects the interest rate on marginal borrowing, I compare how marginal borrowing affects the mortgage interest rate on loans made above the limit with loans made below the limit. To empirically test how losing the MID affects the interest rate on marginal borrowing over the limit, I estimate the following equation using ordinary least squares:

$$
R_{\mathrm{i}}=\alpha+\beta_{1}(\text { Loan Amt })_{\mathrm{i}}+\beta_{2}(\text { Abv Limit })_{\mathrm{i}}+\beta_{3}(\text { Abv Limit * Amt Over Limit })_{\mathrm{i}}+Z_{\mathrm{i}}^{\prime} \gamma+\varepsilon_{\mathrm{i}}
$$

where Loan Amt is a continuous measure of the size of mortgage, measured in thousands of dollars. Abv Limit is a dummy variable that takes the value one for loans made in excess of the 
MID limit and zero otherwise. Amt Over Limit is the dollar amount that the loan exceeds the MID limit by. $\mathrm{Z}$ is a vector of control variables that includes the place of residence, ${ }^{10}$ a dummy variable for non-white applicants, a dummy variable for whether the loan has a co-signer and the income a borrower reports to the lender.

The coefficient $\beta_{1}$ shows how the interest rate changes as the size of mortgage increases for loans below the MID limit. The coefficient $\beta_{2}$ shows how the baseline interest rate changes for loans made above the $\$ 1$ million dollar limit. The coefficient $\beta_{3}$ shows how the baseline interest rate changes for marginal borrowing on loans made above the MID limit, or when the subsidy is no longer available.

There are two ways of testing the effect of the MID using the estimated coefficients from (2). The first is to test if marginal borrowing above the MID limit reduces the interest rate on the loan, or if $\beta_{3}<0$. The second is to test if marginal borrowing above the MID limit changes the interest rate differentially than marginal borrowing below the limit, or if $\beta_{3}=\beta_{1}$. The primary assumption behind this identification strategy is that the factors affecting the interest rate on marginal borrowing below the MID limit are the same as those that affect marginal borrowing above the limit, after accounting for control variables. In other words, that there are no factors outside of the MID limit (and control variables) that would differentially change interest rates on marginal borrowing above the limit.

\subsection{Regression Kink Design}

The nominal limit on the MID makes a method that exploits the abrupt change in policy attractive as a means of identifying the effect of the subsidy on interest rates. If the mortgage interest deduction affects the interest rate lenders charge on a mortgage, then I would expect to see a change in interest rates between loans made for less than the limit compared to loans made 
above the limit. The Regression Kink Design (RKD) is more appropriate than the more common Regression Discontinuity Design (RDD) in this case because the MID limit only affects marginal borrowing over the limit; therefore, I would not expect a large change in interest rates on the entire loan right at the limit, but a more gradual change as the loan grows in excess of the limit. The RDD searches for a "jump" that occurs at the MID limit, where the RKD searches for a difference in slope after the MID limit; therefore, I apply the RKD. The idea behind the RKD is similar to the OLS regressions in (2), to search for a difference in slope; the primary difference is choosing a bandwidth around the MID limit. I follow Card, Lee, and Pei (2009) in applying the RKD. In practice, the RKD requires estimating the following regression:

$$
\begin{aligned}
& R_{\mathrm{i}}=\alpha+\beta_{1}(\text { Loan Amount }- \text { Limit })_{\mathrm{i}}+\beta_{2}(\text { Loan Amount }- \text { Limit })_{\mathrm{i}}{ }^{*}(D=1 \text { if Loan Amount } \geq \text { Limit })+ \\
& \varepsilon_{\mathrm{i}}, \text { where: } \mid \text { Loan Amount-Limit } \mid \leq h
\end{aligned}
$$

where $h$ is the bandwidth around the nominal limit in the regressions. Following Card, Lee, and Pei (2009) I test the estimated coefficient $\beta_{2}=0$, as a way of measuring the effect of losing the MID. If lenders are able to capture some of the MID by charging a higher interest rate, $\beta_{2}$ should be less than zero, or the interest rate on a mortgage above the limit to should decline. I estimate (3) using a range of values for $h$, although the choice of $h$ is quite constrained by available data on mortgages over $\$ 1$ million. Given that I expect how far over the limit a loan is to play a crucial role in how much the interest rate changes, I also estimate (3) using both a symmetric bandwidth around the limit, and a bandwidth that only trims observations where the loan is lower than the limit.

\section{DATA DESCRIPTION}

To estimate (2) and (3), I use a dataset that contains detailed information about home mortgages. Estimation requires knowledge of the purpose of the loan (home purchase), the 
amount of the loan (to determine if it exceeds the limit), and the interest rate charged by the lender. The FFIEC records on mortgage originations for 2004, commonly called HMDA data because it is available as a result of the Home Mortgage Disclosure Act, is ideal for this purpose. The HMDA requires lending institutions to report data on the terms of certain loans and characteristics of applicants to the FFIEC. The level of detail in the HMDA data include controls for the place of residence of the borrower, income (as reported to the lender), coapplicant status of the loan, and race of the borrower.

The HMDA data reports the interest rate variable in terms of a rate spread. The rate spread is the difference between the annual percentage rate (APR) charged at the time of origination and the interest rate that would be earned on a similarly-termed Treasury bond. The use of a rate spread instead of an interest rate avoids any problems associated with comparing interest rates on loans of different terms, by comparing the mortgage with a Treasury bond of a similar term, so that the duration of the loan is not an issue.

The rate spread variable in the data is based on what the law requires financial institutions to report. Before 2003, the FFIEC did not collect information on the rate spread, but a 2002 amendment to the HMDA act required all financial institutions to report the rate spread when it is larger than three percent. ${ }^{11}$ The sample of loans is truncated to be only loans with a rate spread that is three percent or larger. ${ }^{12}$ Although this limits the sample to loans with a relatively high APR, the data are still more detailed than other sources. The limited reporting of the rate spread variable leaves a sample of 918,274 loans made for the purpose of purchasing a home.

Due to the higher APR charged on these loans, the sample for which the rate spread is available is different than the population of loans in the HMDA data. As shown in Table 1, 
home purchase loans in the sample with interest rate information are, on average, about $\$ 75,000$ less than the full sample, although this average is within one standard deviation of the full sample average. Borrowers with interest rate information have about $\$ 20,000$ less in annual income, although this average is still within one standard deviation of the full sample. Nonwhite borrowers are more frequent in this sample, as are loans without a co-signer.

I further restrict the sample used for estimation by only including loans made for above the conforming loan limit set for Fannie Mae and Freddie Mac. The conforming loan limit is the maximum amount of mortgage the government allows Fannie Mae and Freddie Mac to purchase or insure. In 2004, the year of data for this paper, the conforming loan limit was $\$ 333,700$. Hendershott and Shilling (1989) show that the conforming loan limit is an important factor contributing to the interest rate on a mortgage, and loans granted for amounts far in excess of this limit have an interest rate between 15 and 30 basis points larger than comparable loans.

Column (3) of Table 1 shows how the estimation sample differs from both the entire HMDA sample and the sample for which interest rate information is available. Restricting the sample I use for estimation substantially reduces the sample size and increases the average loan amount. The average income of borrowers in the estimation sample is more than double the income of those that have interest rate information. There are more non-whites in the sample, and slightly more loans that are not co-signed. The distribution of where loans originate is also quite different from the population of loans, with the Pacific region representing over 40 percent of the loans in the sample used for estimation.

\section{RESULTS}

\subsection{Marginal Borrowing Results}


I estimate (2) using all home purchase loans in the HMDA data above the conforming loan limit of $\$ 333,700$ and, as a robustness check using all loans made for above $\$ 500,000$. Table 2 shows the results for estimating (2) using both samples. The results presented in Table 2 show a negative relationship between borrowing over the MID limit and mortgage interest rates. The negative sign on $\beta_{3}$ is what is expected if lenders are able to capture some of the MID through higher interest rates, this is evidence that at least some of the subsidy is realized by lenders in the mortgage market.

The point estimates show that the interest rate on the entire mortgage decreases by about 0.0003 for every $\$ 1,000$ borrowed above the limit, or between 3.3 and 4.4 percent. This estimate is not sensitive to using different geographic controls at the state, sub-region, or census region level. The estimates are moderately sensitive to using only loans made in excess of $\$ 500,000$, showing a slightly more negative effect of losing the MID on interest rates.

The estimation results for (2) have two hypotheses of interest. First, loans made in excess of the MID limit have a lower interest rate, or the coefficient $\beta_{3}<0$. Second, the interest rate on marginal borrowing in excess of the MID limit is not equal to the interest rate on marginal borrowing below the limit, or if the coefficients $\beta_{3}-\beta_{1}=0$. Table 2 shows strong evidence in favor of each hypothesis.

I reject the null hypothesis that the coefficient $\beta_{3} \geq 0$, at a significance level less than one percent in specifications using loans above the conforming loan limit, and between the five and ten percent level in specifications using loans above $\$ 500,000$. I also reject the null hypothesis that the coefficient $\beta_{3}=\beta_{1}$, at conventional levels in all specifications. The hypothesis tests show that losing the MID lowers the interest rate on marginal borrowing, and that the interest rate on 
marginal borrowing in excess of the MID limit is lower than the interest rate on marginal borrowing below the limit.

One concern with estimating the relationship between the MID cap and interest rates using Equation (2) is that it is not able to take full advantage of the information on interest rates available in the HMDA data, as it does not include information about loans made with a rate spread less than three. In addition, not using this information may cause a selection problem, as it is lower interest rate loans that are excluded from the sample. Loans that do not report a rate spread have a rate spread between zero and three, making an interval regression an attractive solution to this problem.

Following Long and Freese (2006), the interval regression allows the rate spread variable to be a range of values between zero and three when it is not reported and a value equal to itself when it is reported. This method takes full advantage of the information in the HMDA data and eliminates selection problems by including loans that were not in the data in the previous estimates.

Table 3 presents the results estimated using interval regression. These results are quite similar to the OLS results, and in some cases suggest a stronger relationship between the MID and mortgage interest rates. The point estimates using all loans above the conforming loan limit are in the same range as the OLS results, those using loans above the married filing separate limit show a slightly stronger relationship between the MID and mortgage interest rates. All interval regressions show that the coefficient on the Above Limit*Amount Over Limit variable is statistically significant at less than the one percent level. The interval regression results provide support for the OLS results and show that they are not driven by sample selection in reporting of the rate spread variable. 
Another potential criticism of the identification strategy and subsequent results is that the interest rates may be changing with the size of loan for reasons other than the MID limit. To alleviate this concern, I perform several false experiments using various loan amounts as the MID limit where taxpayers actually retain the full benefit of the MID. I create false limits every $\$ 50,000$ between $\$ 950,000$ and $\$ 750,000$ and run regressions as in (2) to test the hypothesis that the false limit changes interest rates.

The results of the false experiments, presented in Table 3, are encouraging, as they show that a general run-up in interest rates as the loan amount increases does not drive the results in Table 2. In many cases, the coefficient of interest, $\beta_{3}$, has the opposite sign of the regression using the actual limit and in every case fails to reject the null hypothesis that $\beta_{3}$ is positive. I also fail to reject the null hypothesis that the interest rate on marginal borrowing in excess of the limit is equal to the interest rate on marginal borrowing below the limit in all specifications.

\subsection{Regression Kink Design Results}

I estimate the RKD equation both for the sample I have full rate spread information on and for the sample where I either know the actual interest rate or know that it is below 3 using interval regression. Tables 5 and 6 show the estimation results for the discontinuity parameter $\left(\beta_{2}\right)$ for each type of estimation, the top panel of each table shows estimates using a symmetric bandwidth, the bottom panel shows estimates using a bandwidth that is only left censored (leaving all loans above the limit). The RKD results are quite sensitive to the type of censoringthe estimates that censor loans equally on either side of the cap never achieve statistical significance.

RKD estimates that use only left-censoring, trimming loans made for less than the MID limit and retaining loans made in excess of the MID limit, show that interest rates decline when 
the MID is removed on marginal borrowing. The left-censored RKD results are statistically significant for all bandwidths larger than $\$ 100,000$, and all estimates match the negative sign from the OLS results. The magnitude of these results suggests that the interest rate difference from losing the MID is between 0.002 and 0.0011 percentage points on the entire loan. Most of these estimates are in the range of the OLS estimates, but the larger RKD estimates suggest the magnitude of the effect of the MID on interest rates is as much as three times the size of the OLS estimates.

\subsection{Incidence Estimates}

The point estimates in Table 2 provide the basis for calculating the incidence of the MID. The point estimates show how the MID changes the marginal interest rate on borrowing over the limit. To find the marginal interest rate I take the difference between the amount of interest paid on a loan at the limit of $\$ 1,000,000$ with the amount of interest paid on a loan $\$ 1,000$ over the limit, ${ }^{13}$ and divide by the marginal loan amount of $\$ 1,000$. This calculation reveals that the interest rate on marginal borrowing above the limit is on average 3.7 percent lower and ranges between 3.3 and 4.4 percent lower than borrowing below the limit. ${ }^{14}$

Depending on the assumed marginal tax rate and Treasury bond rate, the point estimates from Table 2 imply that lenders capture between 9 and 17 percent of the subsidy created by the MID. Table 5 shows the range of incidence calculations for the low, high and average Treasury bond rate and for both a 25 and 35 percent marginal tax rate. ${ }^{15}$ The assumed marginal tax rate and the Treasury bond rate are negatively related to the percent of the subsidy captured by lenders. Table 5 also provides a 95 percent confidence interval for each estimate using the standard deviation reported for $\beta_{3}$ in Table 2 . 
As demonstrated by the user cost model, a lender's ability to capture some of the MID subsidy has implications for how the subsidy impacts the annual rental price of housing. The user cost model outlined earlier can be used to show how the incidence of the MID is directly related to the annual rental price of housing. In the case of a $\$ 250,000$ purchase price, the high end of the point estimates (17 percent), suggests that the standard model underestimates the annual rental price ${ }^{16}$ of housing by 3.92 percent. The low end of the point estimates ( 9 percent) suggests that the standard model underestimates the annual rental price of housing by 2.07 percent.

The largest point estimates from the interval regression suggest that lenders are able to capture as much as 32 percent of the MID, although most of these estimates suggest the incidence is closer to the OLS results. The point estimates from the RKD suggest that lenders are able to capture as much as 56 percent of the mortgage interest deduction, although these point estimates are quite sensitive to the type of censoring and bandwidth around the limit that is used.

\section{CONCLUSION}

This paper uses the nominal limit on the size of home mortgage that can be claimed for a tax deduction to estimate how much of the subsidy created by the MID is captured by lending institutions. The estimates obtained here show how the MID affects interest rates on a mortgage and are used to show that the interest rate on marginal borrowing without the MID is between 3.3 and 4.4 percent lower than the interest rate with the MID. This estimate implies that lending institutions capture between 9 and 17 percent of the subsidy created by the MID in the form of higher interest rates. The range of incidence estimates depends on the assumed marginal income tax rate as well as the Treasury bond rate. 
Other researchers have shown that buyers and sellers split the incidence of some housing subsidies; however, the findings presented here are the first evidence that the MID affects interest rates in the mortgage market. This finding suggests that refinements to the user-cost model of housing are necessary to determine the impact of the MID on the annual cost of home ownership and house prices. This finding is also important when weighing the costs and benefits of policy proposals to change the current MID or create new subsidies in the tax code for home ownership. The evidence presented here, as well as past research on other housing related subsidies by Devereux and Lanot (2003), Gibbons and Manning (2006) and Susin (2002), suggests that suppliers may partially realize gains in the form of higher prices, rents, or mortgage interest rates from policies intended to make housing more affordable and increase home ownership rates. 
${ }^{1}$ These estimates do not include the implicit subsidy in the tax code that results from not taxing imputed rent.

${ }^{2}$ For a review of these studies, see Anderson, Clemens and Hanson (2007) and Hendershott and White (2000).

${ }^{3}$ Rosen (1979a) highlights the importance of considering how the tax treatment of owner occupied housing may alter gross rents. Some studies, including Berger, et al. (2000) and Capozza, Green, and Hendershott (1999), show that interest rate subsidies are capitalized into house or land prices, but do not examine the effect of these subsidies on interest rates.

${ }^{4}$ Several recent proposals would reduce or change the mortgage interest deduction. These include changing the deduction to a tax credit, proposed by President Obama as well as President George W. Bush's Tax Reform Panel, and limiting the deduction based on the square footage of a home, proposed as part of a carbon reduction plan by Congressman John Dingell (D-MI). The Bush Tax Reform Panel also recommended lowering the cap on interest that can be used for a deduction from the current $\$ 1$ million to a series of caps based on regional home prices. ${ }^{5}$ A lower limit of $\$ 500,000$ applies for married filing separately taxpayers. The $\$ 1$ million limit applies to all other taxpayers.

${ }^{6}$ In a simple supply and demand model of the market for loanable funds, complete pass-through of the subsidy to consumers is equivalent to assuming a perfectly elastic supply curve. If the supply curve is even slightly upward sloping, then lenders and borrowers will split the incidence to some degree.

${ }^{7}$ This calculation assumes a house price purchase price of 250,000 that is fully debt financed, a 25 percent marginal tax rate, 6 percent interest rate and opportunity cost, 2 percent maintenance 
costs, 2.5 percent depreciation, a 1.75 percent property tax rate, and house-price inflation of 3.8 percent.

${ }^{8}$ According to their website, bankrate.com aggregates interest rate information from 4,800 financial institutions in all 50 U.S. states, and they have over 7 million unique visitors monthly. ${ }^{9}$ The limit on deductibility for home equity loans is $\$ 50,000$ for taxpayers who are married filing separately.

${ }^{10}$ Models control for census region, sub-region or state of residence.

${ }^{11}$ HMDA; 12 U.S.C. $§ \$ 2801-10$, amendment effective January 1, 2003.

${ }^{12}$ Estimating using only data restricted by the rate spread variable, combined with an upward sloping yield curve effectively limits the sample to fixed rate mortgages (eliminating adjustable rate mortgages). This seems particularly advantageous given that borrowers with large mortgages may disproportionally opt for adjustable rate mortgages, and thus receive a lower interest rate because of the mortgage instrument, not because of limits on deductibility. ${ }^{13}$ To do this I need to create an interest rate from the rate spread variable available in the HMDA data. I start with the average rate spread of 4.6 and add the either the average, minimum or maximum Treasury Bond interest rates for 2004 for 7, 10, and 20 year bonds, taken from www.ustreas.gov. The average Treasury Bond rate for 2004 was 4.4 and the distribution ranged from 3.17 to 5.61, giving me an average interest rate of 9 percent, and a range of between 7.77 and 10.21 percent. I use this range of interest rates to calculate a range of measures of the incidence of the MID.

${ }^{14}$ I calculate the percentage differences from the baseline interest rate average of 9 , a minimum of 7.77 and a maximum of 10.21 . 
${ }^{15}$ I calculate the percent of the subsidy captured by lenders by dividing the interest rate difference by the amount of subsidy calculated for taxpayers in both the 25 and 35 percent bracket.

${ }^{16}$ This calculation assumes a house price purchase price of 250,000 that is fully debt financed, a 25 percent marginal tax rate, a 6 percent interest rate and opportunity cost, 2 percent maintenance costs, 2.5 percent depreciation, a 1.75 percent property tax rate, and house-price inflation of 3.8 percent. 


\section{REFERENCES}

Anderson, John, Jeffrey Clemens, and Andrew Hanson. 2007. Capping the Mortgage Interest Deduction. National Tax Journal 60 (4): 769-785.

Berger, Tommy, Peter Englund, Patric Hendershott, and Bengt Turner. 2000. Another Look at the Capitalization of Interest Subsidies: Evidence from Sweden. Journal of Money, Credit and Banking 32 (2): 199-217.

Capozza, Dennis, Richard Green, and Patric Hendershott. 1999. Tax Reform and House Prices: Large or Small Effect? Proceedings of the $91^{\text {st }}$ Annual National Tax Association Conference: $19-24$.

Card, David, David Lee, and Ahuan Pei. 2009. Quasi-Experimental Identification and Estimation in the Regression Kink Design. Princeton University Industrial Relations Section Working Paper 553, Princeton, New Jersey.

Devereux, Michael and Gauthier Lanot. 2003. Measuring tax incidence: an application to mortgage provision in the U.K. Journal of Public Economics 87 (7): 1747-1778.

Executive Office of the President, Office of Management and Budget. 2010. Analytical Perspectives, Budget of the United States Government Fiscal Year 2011. U.S. Government Printing Office, Washington, DC. 
Gibbons, Stephen and Alan Manning. 2003. The incidence of UK housing benefit: Evidence from the 1990s reforms. Centre for Economic Performance Discussion Paper 597, London, UK.

Gibbons, Stephen and Alan Manning. 2006. The incidence of UK housing benefit: Evidence from the 1990s reforms. Journal of Public Economics 90 (4): 799-822.

Glaeser, Edward and Jesse Shapiro. 2003. The Benefits of the Home Mortgage Interest Deduction. Tax Policy and the Economy (Volume 17), James Poterba, ed., 37-82. Cambridge, MA: MIT Press.

Green, Richard and Kerry Vandell. 1999. Giving Households Credit: How Changes in the U.S. Tax Code Could Promote Homeownership. Regional Science and Urban Economics 29 (4): $419-444$.

Himmelberg, Charles, Christopher Mayer, and Todd Sinai. 2005. Assessing High House Prices: Bubbles, Fundamentals, and Misperceptions. Journal of Economic Perspectives 19 (4): 67-92.

Hendershott, Patric and White, Michael. 2000. Taxing and Subsidizing Housing Investment: The Rise and Fall of Housing's Favored Status. National Bureau of Economic Research Working Paper 7928, Cambridge, MA.

Hendershott, Patric and Shilling, James. 1989. The Impact of the Agencies on Conventional Fixed-Rate Mortgage Yields. Journal of Real Estate Finance and Economics 2 (2): 101-115. 
Long, J. Scott and Jeremy Freese. 2006. Regression Models for Categorical and Limited Dependent Variables Using Stata. 2nd ed. College Station, TX: Stata Press.

Poterba, James. 1992. Taxation and Housing: Old Questions, New Answers. American Economic Review 82 (2): 237-242.

Poterba, James. 1984. Tax Subsidies to Owner-Occupied Housing: An Asset Market Approach. Quarterly Journal of Economics 99 (4): 729-752.

Rosen, Harvey. 1985. Housing Subsidies: Effects on Housing Decisions, Efficiency, and Equity. In Handbook of Public Economics (Volume 1), edited by Martin Feldstein and Alan Auerbach, eds., 375-420. Amsterdam, Netherlands: North-Holland Press.

Rosen, Harvey. 1979(a). Housing Decisions and the U.S. Income Tax: An Econometric Analysis. Journal of Public Economics 11 (1): 1-23.

Rosen, Harvey. 1979(b). Owner Occupied Housing and the Federal Income Tax: Estimates and Simulations. Journal of Urban Economics 6 (2): 247-266.

Susin, Scott. 2002. Rent vouchers and the price of low-income housing. Journal of Public Economics 83 (1): 109-152. 
Wheaton, William. 1990. Vacancy, search, and prices in a housing market matching model. Journal of Political Economy 98 (6): 1270-1292. 
Andrew Hanson is an assistant professor in the department of economics at Georgia State University. He received his doctorate in economics from Syracuse University. Much of his work has focused on evaluating the effect of geographically targeted tax incentives. He has also worked on research related to tax incidence and housing markets. 
Table 1

2004 HMDA Summary Statistics for Home Purchase Loan Originations (standard errors in parentheses)

\begin{tabular}{|c|c|c|c|}
\hline & $\begin{array}{l}\text { All Mortgage } \\
\text { Originations }\end{array}$ & $\begin{array}{l}\text { Mortgage Originations } \\
\text { reporting rate spread }\end{array}$ & $\begin{array}{c}\text { Mortgage Originations } \\
\text { reporting rate spread, } \\
\text { Over Conforming Loan } \\
\text { Limit }\end{array}$ \\
\hline $\mathrm{N}$ & $6,380,690$ & 918,274 & 32,715 \\
\hline \multicolumn{4}{|l|}{ Average Loan } \\
\hline Amount (\$) & $\begin{array}{c}178,962 \\
(223,564)\end{array}$ & $\begin{array}{l}104,234 \\
(99,598)\end{array}$ & $\begin{array}{c}439,044 \\
(175,196)\end{array}$ \\
\hline Average Income (\$) & $\begin{array}{c}93,701 \\
(134,784)\end{array}$ & $\begin{array}{c}74,053 \\
(84,499)\end{array}$ & $\begin{array}{c}162,401 \\
(190,564)\end{array}$ \\
\hline Non-White (percent) & 26.00 & 35.02 & 42.80 \\
\hline Co-Signed (percent) & 47.8 & 30.2 & 33.08 \\
\hline \multicolumn{4}{|l|}{$\begin{array}{l}\text { Place of Residence } \\
\text { (percent) }\end{array}$} \\
\hline East-North Central & 13.84 & 14.85 & 5.30 \\
\hline West-North Central & 5.84 & 5.47 & 1.40 \\
\hline Mountain & 10.25 & 9.77 & 4.80 \\
\hline Pacific & 18.29 & 18.13 & 43.50 \\
\hline South Atlantic & 23.53 & 22.43 & 15.30 \\
\hline East-South Central & 4.65 & 5.82 & 1.10 \\
\hline West-South Central & 9.84 & 12.65 & 2.90 \\
\hline New England & 4.37 & 3.69 & 5.70 \\
\hline Mid Atlantic & 9.39 & 7.19 & 20.00 \\
\hline
\end{tabular}

Source: Author's calculations using 2004 FFIEC Home Mortgage Disclosure Act Data 
Table 2

Effect of the Mortgage Interest Deduction on Interest Rates for Home Purchase Loans (standard errors in parentheses, p-values in brackets)

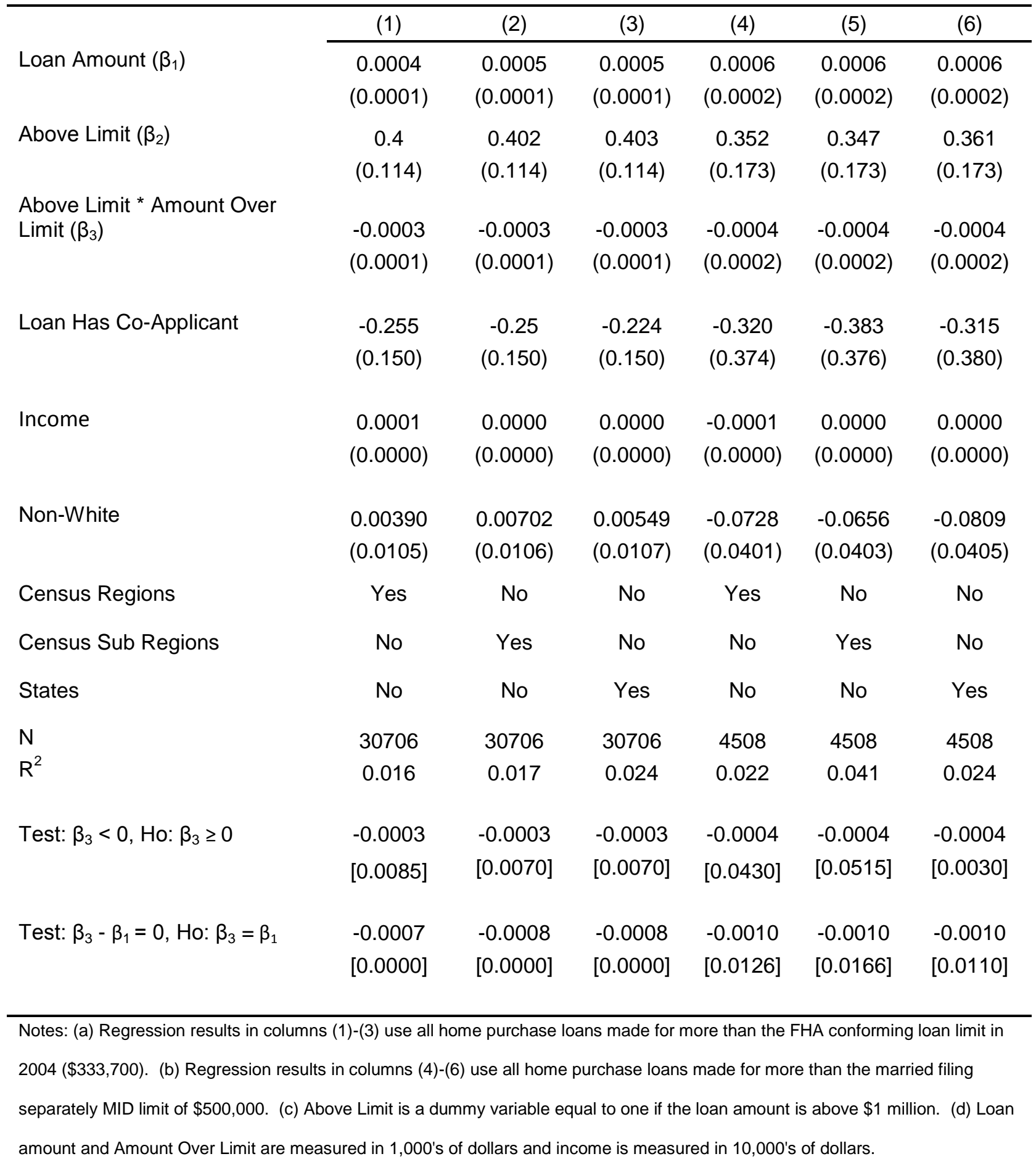


Table 3

Interval Regression Results for Effect of the Mortgage Interest Deduction on Interest Rates for Home Purchase Loans (standard errors in parentheses, p-values in brackets)

\begin{tabular}{|c|c|c|c|c|c|c|}
\hline & $(1)$ & (2) & (3) & (4) & (5) & (6) \\
\hline Loan Amount $\left(\beta_{1}\right)$ & $\begin{array}{c}0.0005 \\
(0.0001)\end{array}$ & $\begin{array}{c}0.0005 \\
(0.0001)\end{array}$ & $\begin{array}{c}0.0005 \\
(0.0001)\end{array}$ & $\begin{array}{c}0.0008 \\
(0.0001)\end{array}$ & $\begin{array}{c}0.0007 \\
(0.0001)\end{array}$ & $\begin{array}{c}0.0007 \\
(0.0001)\end{array}$ \\
\hline Above Limit $\left(\beta_{2}\right)$ & $\begin{array}{c}0.392 \\
(0.112)\end{array}$ & $\begin{array}{c}0.394 \\
(0.112)\end{array}$ & $\begin{array}{l}0.0397 \\
(0.112)\end{array}$ & $\begin{array}{c}0.252 \\
(0.136)\end{array}$ & $\begin{array}{c}0.246 \\
(0.136)\end{array}$ & $\begin{array}{c}0.242 \\
(0.136)\end{array}$ \\
\hline Above Limit * Amount Over Limit $\left(\beta_{3}\right)$ & $\begin{array}{l}-0.0003 \\
(0.0001)\end{array}$ & $\begin{array}{l}-0.0004 \\
(0.0001)\end{array}$ & $\begin{array}{l}-0.0004 \\
(0.0001)\end{array}$ & $\begin{array}{l}-0.0006 \\
(0.0002)\end{array}$ & $\begin{array}{l}-0.0006 \\
(0.0002)\end{array}$ & $\begin{array}{l}-0.0006 \\
(0.0002)\end{array}$ \\
\hline Loan Has Co-Applicant & $\begin{array}{l}-0.254 \\
(0.148)\end{array}$ & $\begin{array}{l}-0.249 \\
(0.148)\end{array}$ & $\begin{array}{l}-0.244 \\
(0.148)\end{array}$ & $\begin{array}{l}-0.297 \\
(0.303)\end{array}$ & $\begin{array}{l}-0.357 \\
(0.308)\end{array}$ & $\begin{array}{l}-0.368 \\
(0.308)\end{array}$ \\
\hline Income & $\begin{array}{c}0.0001 \\
(0.0000)\end{array}$ & $\begin{array}{c}0.0000 \\
(0.0000)\end{array}$ & $\begin{array}{c}0.0000 \\
(0.0000)\end{array}$ & $\begin{array}{c}0.0000 \\
(0.0000)\end{array}$ & $\begin{array}{c}0.0000 \\
(0.0000)\end{array}$ & $\begin{array}{c}0.0000 \\
(0.0000)\end{array}$ \\
\hline Non-White & $\begin{array}{l}0.00199 \\
(0.0103)\end{array}$ & $\begin{array}{l}0.00508 \\
(0.0104)\end{array}$ & $\begin{array}{c}0.0071 \\
(0.0138)\end{array}$ & $\begin{array}{l}-0.0853 \\
(0.0309)\end{array}$ & $\begin{array}{c}-0.0802 \\
(0.0311)\end{array}$ & $\begin{array}{l}-0.0719 \\
(0.0296)\end{array}$ \\
\hline Census Regions & Yes & No & No & Yes & No & No \\
\hline Census Sub Regions & No & Yes & No & No & Yes & No \\
\hline States & No & No & Yes & No & No & Yes \\
\hline $\mathrm{N}$ & 633458 & 633459 & 633460 & 204325 & 204325 & 204325 \\
\hline Test: $\beta_{3}<0, \mathrm{Ho}: \beta_{3} \geq 0$ & $\begin{array}{c}-0.0003 \\
{[0.0065]}\end{array}$ & $\begin{array}{c}-0.0004 \\
{[0.0055]}\end{array}$ & $\begin{array}{l}-0.0004 \\
{[0.0055]}\end{array}$ & $\begin{array}{c}-0.0006 \\
{[0.0010]}\end{array}$ & $\begin{array}{c}-0.0006 \\
{[0.0010]}\end{array}$ & $\begin{array}{c}-0.0006 \\
{[0.0010]}\end{array}$ \\
\hline Test: $\beta_{3}-\beta_{1}=0, \mathrm{Ho}: \beta_{3}=\beta_{1}$ & $\begin{array}{l}-0.0008 \\
{[0.0005]}\end{array}$ & $\begin{array}{c}-0.0008 \\
{[0.0000]}\end{array}$ & $\begin{array}{c}-0.0008 \\
{[0.0000]}\end{array}$ & $\begin{array}{c}-0.0014 \\
{[0.0000]}\end{array}$ & $\begin{array}{c}-0.0014 \\
{[0.0000]}\end{array}$ & $\begin{array}{c}-0.0014 \\
{[0.0000]}\end{array}$ \\
\hline
\end{tabular}


Table 4

False Experiments for MID limit on Home Purchase Loans (standard errors in parentheses, $p$-values in brackets)

\begin{tabular}{|c|c|c|c|c|c|}
\hline & $\begin{array}{c}\text { Limit at } \\
\$ 950,000 \\
(1)\end{array}$ & $\begin{array}{c}\text { Limit at } \\
\$ 900,000 \\
(2)\end{array}$ & $\begin{array}{c}\text { Limit at } \\
\$ 850,000 \\
(3)\end{array}$ & $\begin{array}{c}\text { Limit at } \\
\$ 800,000 \\
(4)\end{array}$ & $\begin{array}{c}\text { Limit at } \\
\$ 750,000 \\
(5)\end{array}$ \\
\hline Loan Amount $\left(\beta_{1}\right)$ & $\begin{array}{c}0.0006 \\
(0.0002)\end{array}$ & $\begin{array}{c}0.0006 \\
(0.0002)\end{array}$ & $\begin{array}{c}0.0005 \\
(0.0002)\end{array}$ & $\begin{array}{c}0.0007 \\
(0.0003)\end{array}$ & $\begin{array}{c}0.0005 \\
(0.0003)\end{array}$ \\
\hline Above Limit $\left(\beta_{2}\right)$ & $\begin{array}{l}-0.226 \\
(0.381)\end{array}$ & $\begin{array}{c}0.210 \\
(0.305)\end{array}$ & $\begin{array}{c}0.119 \\
(0.234)\end{array}$ & $\begin{array}{l}-0.265 \\
(0.185)\end{array}$ & $\begin{array}{c}0.175 \\
(0.127)\end{array}$ \\
\hline Above Limit * Amount Over Limit $\left(\beta_{3}\right)$ & $\begin{array}{c}0.0048 \\
(0.0142)\end{array}$ & $\begin{array}{l}-0.0041 \\
(0.0051)\end{array}$ & $\begin{array}{c}-0.0012 \\
(0.00266)\end{array}$ & $\begin{array}{c}0.0014 \\
(0.00162)\end{array}$ & $\begin{array}{l}-0.0009 \\
(0.0010)\end{array}$ \\
\hline $\begin{array}{l}N \\
\mathrm{R}^{2}\end{array}$ & $\begin{array}{l}4315 \\
0.030\end{array}$ & $\begin{array}{l}4315 \\
0.030\end{array}$ & $\begin{array}{l}4315 \\
0.030\end{array}$ & $\begin{array}{l}4315 \\
0.030\end{array}$ & $\begin{array}{l}4315 \\
0.030\end{array}$ \\
\hline Test: $\beta_{3}<0, \mathrm{Ho}: \beta_{3} \geq 0$ & $\begin{array}{c}0.0048 \\
{[0.3665]}\end{array}$ & $\begin{array}{r}-0.0041 \\
{[0.214]}\end{array}$ & $\begin{array}{l}-0.0012 \\
{[0.3250]}\end{array}$ & $\begin{array}{c}0.0014 \\
{[0.2005]}\end{array}$ & $\begin{array}{c}-0.0009 \\
{[0.1510]}\end{array}$ \\
\hline Test: $\beta_{3}-\beta_{1}=0, \mathrm{Ho}: \beta_{3}=\beta_{1}$ & $\begin{array}{c}0.0042 \\
{[0.7651]}\end{array}$ & $\begin{array}{l}-0.0047 \\
{[0.3686]}\end{array}$ & $\begin{array}{c}-0.00316 \\
{[0.5186]}\end{array}$ & $\begin{array}{c}-0.00232 \\
{[0.7117]}\end{array}$ & $\begin{array}{c}-0.0015 \\
{[.1908]}\end{array}$ \\
\hline
\end{tabular}


Table 5

Regression Kink Design Estimates of the Effect of the MID on Interest Rates for Home Purchase Loans ( $p$-value in brackets)

\begin{tabular}{ccccc}
\hline & \multicolumn{4}{c}{ Bandwidth Around Limit } \\
Symmetric Bandwidth \\
N over, N under & $\$ 100,000$ & $\$ 200,000$ & $\$ 300,000$ & $\$ 400,000$ \\
\cline { 2 - 5 }$\beta_{2}$ & 63,102 & 91,250 & 118,689 & 136,1740 \\
Ho: $\beta_{2}=0$ & 0.0081 & 0.0001 & -0.0004 & 0.0007 \\
& {$[0.325]$} & {$[0.950]$} & {$[0.766]$} & {$[0.512]$} \\
Left-Censored Bandwidth & & & & \\
N over, N under & 285,102 & 285,250 & 285,689 & 285,1740 \\
$\beta_{2}$ & -0.0003 & -0.0004 & -0.0011 & -0.0008 \\
Ho: $\beta_{2}=0$ & {$[0.335]$} & {$[0.026]$} & {$[0.015]$} & {$[0.030]$} \\
\hline
\end{tabular}


Table 6

Regression Kink Design Estimated with Interval Regression of the Effect of the MID on Interest Rates for Home Purchase Loans

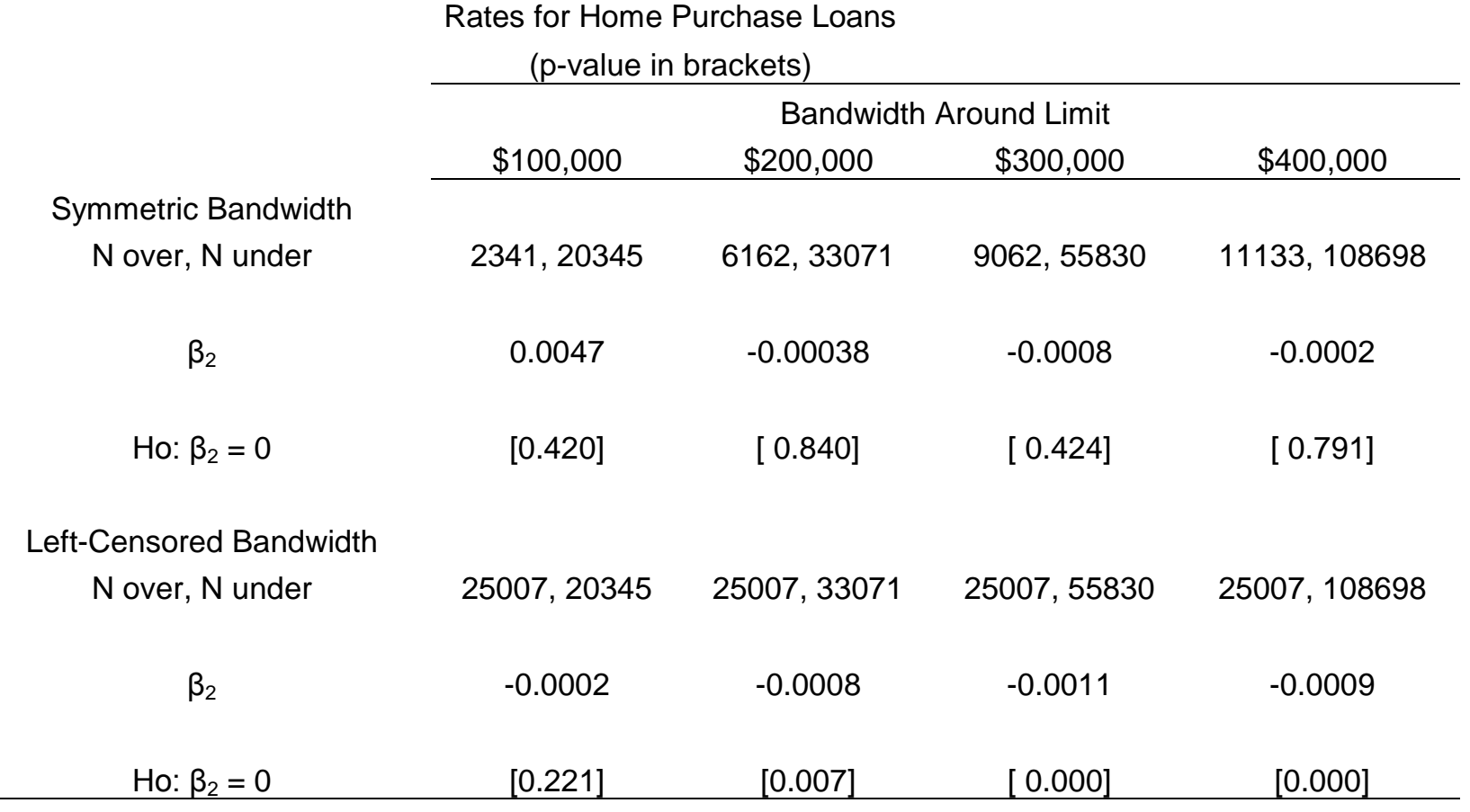


Table 7

Mortgage Interest Deduction Incidence Calculations

\begin{tabular}{lcccccc}
\hline T-Bill Rate & \multicolumn{2}{c}{ Low $=.0317$} & \multicolumn{2}{c}{ High $=.0561$} & \multicolumn{2}{c}{ Average $=.046$} \\
Marginal Tax Rate & 0.25 & 0.35 & 0.25 & 0.35 & 0.25 & 0.35 \\
& & & & & & \\
& 0.17 & 0.12 & 0.13 & 0.09 & 0.14 & 0.10 \\
$\begin{array}{l}\text { Subsidy to Lenders } \\
\begin{array}{l}\text { I5 percent Confidence } \\
\text { Interval }\end{array}\end{array}$ & $(.07, .27)$ & $(.05, .19)$ & $(.05, .21)$ & $(.03, .15)$ & $(.06, .23)$ & $(.04, .16)$
\end{tabular}

Notes: (a) Treasury Bond rates are daily rates on 7, 10 and 20 year bonds 2004 from, www.ustreas.gov. (b) Marginal tax rates are from 2004. (b) Point estimates and 95 percent confidence interval are the author's calculations using estimates from Table 3. 